УДК 316.42 (512.36)

БАДАРАЕВ Дамдин Доржиевич - кандидат социологических наук, доцент; старший научный сотрудник Института монголоведения, буддологии и тибетологии СО РАН (670047, Россия, Республика Бурятия, г. Улан-Удэ, ул. Сахьяновой, 6; damdin80@таil.ru)

БАДОНОВ Алексей Маланович - кандидат социологических наук; доцент кафедры теории социальной работы Бурятского государственного университета им. Доржи Банзарова (670000, Россия, Республика Бурятия, г. Улан-Удэ, ул. Смолина, 24a; badonov@таil.ru)

\title{
ВЛИЯНИЕ ПРОЦЕССОВ ГЛОБАЛИЗАЦИИ НА СИСТЕМУ ЖИЗНЕОБЕСПЕЧЕНИЯ МОНГОЛЬСКОГО ОБЩЕСТВА
}

\begin{abstract}
Аннотация. В статье рассматриваются особенности системы жизнеобеспечения монгольского общества, изменяющиеся под влиянием процессов глобализации. На основе статистических данных и показателей индекса человеческого развития авторы определяют и анализируют основные тенденции изменения общества, такие как усиление центростремительных процессов в стране, которые приводят к росту значения городов в жизни населения. Авторы отмечают, что урбанизационные явления приводят к ускоренному развитию инфраструктуры столицы Улан-Батора, однако при этом возникают проблемы, связанные с обеспечением нормального функционирования системы жизнеобеспечения монгольского общества.
\end{abstract}

Ключевые слова: глобализация, система жизнеобеспечения, Монголия, индекс человеческого развития, традиционная культура

B условиях глобализирующегося общества постсоциалистические страны продолжают трансформироваться, активно внедряя новшества и модернизационные изменения в существующий ранее общественный уклад. Ярким примером такого общества является современная Монголия, которая рассматривается в академических кругах в самых разных образах: например, как «страна резких контрастов», «оазис демократии в Центральной Азии», «кочевая цивилизация», «земля, богатая природными ресурсами», «колыбель легенд» и т.д. Несомненно, такие сравнения связаны со спецификой уникальной истории и культуры страны, природы, обычаев, традиций, образа жизни и менталитета народа, а также теми новациями и тенденциями, которые присущи современной Монголии. В таких условиях интенсивные изменения претерпевает система жизнеобеспечения монгольского общества. Под системой жизнеобеспечения общества подразумевается комплекс условий, обеспечивающих комфортную и приемлемую среду для проживания, жизнедеятельности и функционирования общества. В этом ключе к общепризнанным показателям уровня развития общества, а также системы его жизнеобеспечения в международной практике можно отнести Индекс человеческого развития (ИЧР), который включает в себя такие показатели, как ожидаемая продолжительность жизни, уровень грамотности населения, уровень жизни населения. В данной статье рассматриваются особенности воздействия процессов глобализации на систему жизнеобеспечения монгольского общества, а также особенности влияния традиционной культуры на повседневные практики населения Монголии.

В целях демонстрации основных социальных показателей жизнеобеспечения монгольского общества ниже представлена таблица, содержащая социальнодемографические данные за 2007-2016 гг.

Из данных табл. 1 видно, что за указанное десятилетие численность населения увеличилась на $19,1 \%$, с чем связаны изменения и в других демографи- 
Таблица 1

Динамика социально-экономических показателей Монголии, 2007-2016 гг. *

\begin{tabular}{|c|c|c|c|}
\hline $\begin{array}{l}\text { № } \\
\text { II/I }\end{array}$ & Показатели & 2007 & 2016 \\
\hline 1 & Численность населения, тыс. чел. & 2620,5 & 3119,9 \\
\hline 2 & Плотность населения на 1 кв. км & 1,7 & 2,0 \\
\hline 3 & Городское население, тыс. чел. & 1655,5 & 2131,8 \\
\hline 4 & Сельское население, тыс. чел. & 965,0 & 988,0 \\
\hline 5 & Численность населения г. Улан-Батора, тыс. чел. & 1098,8 & 1440,0 \\
\hline 6 & Экономически активное население, тыс. чел. & 1013,4 & 1275,6 \\
\hline 7 & Экономически неактивное население, тыс. чел. & 602,0 & 831,4 \\
\hline 8 & $\begin{array}{l}\text { Занятые, уровень занятости, тыс. чел. / } \\
\text { доля рабочей силы, \% }\end{array}$ & $899,0 / 54,5$ & $1147,8 / 54,5$ \\
\hline 9 & $\begin{array}{l}\text { Безработные, уровень безработицы, тыс. чел. / } \\
\text { доля рабочей силы, \% }\end{array}$ & $114,5 / 11,3$ & $127,8 / 10$ \\
\hline 10 & Зарегистрированные безработные, тыс.чел. & 29,9 & 34,4 \\
\hline 11 & Уровень бедности, \%, в т.ч.: & 35,2 & 29,6 \\
\hline 12 & Городское население & 26,9 & 27,1 \\
\hline 13 & Сельское население & 46,6 & 34,9 \\
\hline 14 & Уровень смертности, на 1000 чел., \% & 6,2 & 5,8 \\
\hline 15 & Уровень рождаемости, на 1000 чел., \% & 21,8 & 25,9 \\
\hline 16 & Уровень заключения браков, на 1000 чел., \% & 24,5 & 8,3 \\
\hline 17 & Уровень числа разводов, на 1000 чел., \% & 1,1 & 2,0 \\
\hline 18 & Средняя продолжительность жизни, лет, в т.ч.: & 66,54 & 69,57 \\
\hline 19 & Мужчины & 63,13 & 65,58 \\
\hline 20 & Женщины & 70,23 & 75,10 \\
\hline
\end{tabular}

Монгол улсын статистикийн эмхэтгэл 2016 [Статистический ежегодник Монголии 2016]. 2017. Улаанбаатар. 652 с.

ческих показателях. Эти изменения связаны с показателями урбанизации населения Монголии: за десятилетие городское население увеличилось на $28,7 \%$, а численность столичных жителей - на $31 \%$. Такие изменения связаны с ростом качественных показателей систем жизнеобеспечения. ИЧР Монголии, по данным 2018 г., составил 0,740. Динамику изменения показателей ИЧР за 20072016 гг. и отдельных индексов, формирующих этот показатель, демонстрируют данные табл. 2.

Как видно из данных, приведенных в табл. 2, за 2007-2016 гг. ИЧР Монголии характеризуется определенной неустойчивостью, что связано с изменениями соотношения между тремя индексами, из которых формируется ИЧР. Так, два индекса «продолжительность жизни в Монголии» и «ВВП / ВНД (валовый внутренний доход до 2010 г. / валовый национальный доход с 2011 г.) на 1 чел. по паритету покупательной способности (ППС) на душу населения» на протяжении указанного срока демонстрировали положительную динамику, тогда как индекс «грамотность населения» за эти годы существенно снизился. Кроме того, анализ статистических данных по уровню бедности населения и индексу валового дохода показывает, что рост валовых показателей не обеспечивает зна- 
Таблица 2

Индекс человеческого развития в Монголии, 2007-2016 гг. *

\begin{tabular}{|c|l|c|c|c|c|}
\hline $\begin{array}{c}\text { № } \\
\text { п/п }\end{array}$ & \multicolumn{1}{|c|}{ Индексы } & $\mathbf{2 0 0 7}$ & $\mathbf{2 0 1 0}$ & $\mathbf{2 0 1 3}$ & $\mathbf{2 0 1 6}$ \\
\hline 1 & Индекс человеческого развития, в т.ч.: & 0,737 & 0,756 & 0,726 & 0,734 \\
\hline 2 & Индекс средней продолжительности жизни & 0,692 & 0,718 & 0,756 & 0,763 \\
\hline 3 & Индекс уровня грамотности & 0,922 & 0,928 & 0,724 & 0,728 \\
\hline 4 & Индекс ВВП/ВНД на 1 чел. & 0,597 & 0,623 & 0,701 & 0,712 \\
\hline
\end{tabular}

* * Монгол улсын статистикийн эмхэтгэл 2016 [Статистический ежегодник Монголии 2016]. 2017. Улаанбаатар. С. 195-196.

чимый рост уровня жизни монгольского населения, что вызвано внутренней политикой страны, состоянием кредитно-денежной политики страны, финансовыми обязательствами перед международными организациями. На повышение ИЧР оказывают существенное влияние международные организации: Международный валютный фонд, Всемирный банк, Азиатский банк развития, ПРООН, а также страны-доноры, предоставляющие Монголии финансовую и гуманитарную помощь в разные периоды экономического спада и социальноэкономической нестабильности [Грайворонский 2017: 119].

Систему жизнеобеспечения монгольского общества можно условно дифференцировать по двум уровням: город/столица как территория новых возможностей; худон / сельская местность как пространство кочевого образа жизни.

Монголия является уникальной страной, сохранившей кочевой образ жизни и номадическую культуру в современном мире [Бадараев и др. 2017]. С началом постсоциалистической трансформации процесс вхождения страны в глобализацию ускорился. Открытие границ, активизация страны в сфере дипломатических отношений и международного сотрудничества привели к росту инвестиционной привлекательности для иностранных горнорудных компаний, развитию международного туризма, академической и образовательной мобильности. Огромное влияние на менталитет монголов и систему жизнеобеспечения общества оказало развитие информационных технологий. Импорт товаров широкого потребления, бытовой техники, автомобилей из Японии, Китая, Южной Кореи и других стран также привели к изменению ритма жизни в недавнем прошлом кочевого народа. Строительство сети автомобильных дорог под названием «Мянганы зам» («Дорога тысячелетия») позволило связать асфальтированными дорогами все аймачные центры со столицей Улан-Батором. Массовое строительство многоэтажных микрорайонов с градацией по уровню экологичности и элитности за десятилетие преобразило столицу страны. Юрточные микрорайоны, расположенные на окраинах столицы, также видоизменяются: на многих земельных участках рядом с традиционной юртой активно воздвигаются таун-хаусы и 2-3-этажные коттеджи. В столице наиболее заметными являются проблемы сельской миграции, увеличение юрточных микрорайонов, безработица, бедность, смог в столице, транспортные пробки и т.д. Все отмеченные проблемы тесно взаимосвязаны, имеют социально значимый и перманентный характер. Одним из резонансных достижений властей столицы и правительства страны стало снижение уровня смога в Улан-Баторе в отопительный сезон 2019/2020 гг. 70-80\% загрязнения воздуха столицы возникает в результате сжигания сырого угля в юрточных микрорайонах столицы, где проживают до 800 тыс. жителей. Эта проблема стала одной из самых обсуждаемых среди широкой общественности. Использование брикетированного угля, производ- 
ство которого осушествляет лишь один завод в Улан-Баторе, а также введенный 15 мая 2019 г. запрет на сжигание сырого угля для бытовых нужд существенно снизили загрязнение воздуха в столице. Планируется строительство второго завода в середине 2020 г. ${ }^{1}$

Учитывая имеющиеся проблемы урбанизированного полиса и позитивные преобразования, можно констатировать, что современный Улан-Батор - город больших возможностей, с развитой инфраструктурой, крупными торговыми центрами, многочисленными образовательными, медицинскими, научными и культурными учреждениями, обеспечивающими условия для нормального проживания для жителей и гостей столицы.

В сельской местности система жизнеобеспечения после распада социалистической системы также претерпела трансформацию. Изменение форм собственности через приватизацию коллективной собственности привело к индивидуализации жизнедеятельности аратов. Вместе с тем муниципальные органы власти выполняют основные функции по реализации государственных законов и принятых на их основе местных нормативно-правовых актов. В сельской местности большинство объектов социальной инфраструктуры остается под вертикальным государственным управлением. Коммерческие структуры - магазины, киоски, гостиницы, рестораны, кафе - принадлежат частным собственникам.

Данные нескольких экспедиционных исследований показывают, что в основе кочевого образа жизни монгольских скотоводов также наметились определенные изменения ${ }^{2}$. В первую очередь, они связаны с активным использованием современных средств связи и сельскохозяйственного транспорта, техники и бытового оборудования. Скотоводы-кочевники активно пользуются сотовой и спутниковой связью для общения не только в пределах своей страны, но и с далеким зарубежьем.

Модернизированное пастбищное скотоводство монгольских кочевников сочетает в себе признаки неотрадиционализма и современных вызовов глобализации. В 2019 г. поголовье скота в Монголии впервые достигло 70969315 голов. Численность скотоводов в 2018 г. составила 288700 чел. ${ }^{3}$ При выпасе скота обычно используется мотоцикл - «современная лошадь кочевника», которым пользуются скотоводы вне зависимости от пола и возраста. При сезонных кочевках используются микрогрузовики. Для современных скотоводов заготовка кормов на зиму для особых случаев (бескормица, ранний приплод, природные катаклизмы) благодаря использованию сельскохозяйственной техники становится нормальным явлением. Сомонные и аймачные центры представляют собой ключевой инфраструктурный узел для жизнедеятельности сельских жителей Монголии. Здесь представлены учреждения и организации, с которыми сельчане, в частности скотоводы, непосредственно связаны при осуществлении жизнедеятельности и традиционных хозяйственных практик. Как правило, скотоводы, несмотря на кочевой образ жизни, имеют свои стационарные дома в сомонных центрах.

При индивидуализированной форме жизнедеятельности домохозяйств пре-

1 В Монголии появится второй завод по брикетированию угля. 2020. Доступ: http://asiarussia. ru/news/22959/ (проверено 05.02.2020); Источником смога в Улан-Баторе является государство. 06.02.2018. Доступ: http://asiarussia.ru/articles/18920/ (проверено 05.02.2020).

2 Экспедиционные исследования в составе комплексных групп ИМБТ СО РАН осуществлены в 2011 г. в Южногобийском и Кобдосском аймаках, в 2017 г. - в Булганском, Дорнодском и Хэнтэйском аймаках.

3 Статистикийн мэдээллийн нэгдсэн сан [Единый фонд статистической информации]. - Caйm Национального статистического комитета Монголии «1212.mn». 2020. Доступ: http://www.1212.mn (проверено 09.02.2020). 
валируют рыночные принципы ведения хозяйства. Монгольские скотоводы торгуют мясом, овечьей шерстью, козьим пухом, шкурами, получаемый доход от которых зависит от закупочной цены - прямой поставки до потребителя и числа посредников. Разница в ценах в худоне и на городском рынке может доходить до 2-3 раз в зависимости от качества продукции, сезона ее реализации, транспортной доступности и т.д.

В войлочных юртах состоятельных кочевников используются не только традиционная мебель, посуда и домашняя утварь, но и современные виды домашней техники - морозильники, холодильники, телевизоры, компьютеры и ноутбуки, светильники, магнитолы и музыкальные центры, электрочайники и др. Однако ветряные и солнечные батареи не обеспечивают надежное электроснабжение электрической техники и оборудования в течение длительного времени. Безвизовое посещение монголами соседних стран - Китая и России - обеспечивает возможности для массового импорта зарубежных товаров для использования скотоводами в своей хозяйственной практике. В традиционном скотоводстве самыми актуальными проблемами являются рациональное использование пастбищных угодий и колодцев с питьевой водой. Качество питьевой воды практически не проверяется. Отдельная проблема в сельской Монголии - промышленный прессинг горнорудных компаний на пастбищные территории скотоводов. Также не хватает ветеринарных станций для обеспечения полноценной защиты многотысячных стад. Слабость ветеринарного контроля является одной из известных причин запрета экспорта монгольского мяса за рубеж, в т.ч. и в Россию.

Неформальная занятость имеет особую актуальность в сельской Монголии, что связано с низким уровнем жизни населения. Уровень бедности в Монголии остается высоким (в 2018 г. - 28,4\%), достигая в отдельные годы половины сельского населения (в 2009 г. - 49,6\%). Отсутствие стабильно оплачиваемой работы вынуждает молодежь и население трудоспособного возраста в поисках заработка отправляться в крупные населенные пункты или за рубеж. Выходцы из худона в общей массе занимаются низкоквалифицированным трудом за исключением лиц, обладающих конкурентными профессиями на рынке труда. В некоторых аймаках до сих пор продолжается нелегальная добыча золота так называемыми ниндзя, несмотря на ужесточение законодательства в сфере горнорудной промышленности [Бадараев 2014]. В отдельные годы объем нелегальной добычи золота достигал половины всего добываемого золота Монголии. Золото в основном переправляется в соседний Китай через теневые каналы поставки контрабандного груза.

Таким образом, современное монгольское общество активно модернизируется под влиянием глобализирующегося мирового сообщества. В Монголии сохраняется традиционный жизненный уклад в рамках кочевого образа жизни, который также трансформируется в результате научно-технического развития общества. Наиболее яркие проявления глобализационного воздействия представлены в Улан-Баторе, который стал центром притяжения для всего населения страны. С актуализацией вызовов модернизации для монгольского общества возникают новые угрозы утраты самобытности, сохранения исконных традиционных видов хозяйственных практик, обычаев, традиций и культуры народа.

Статья подготовлена в рамках государственного задания (проект ХІІ.191.1.1. «Трансграничье России, Монголии и Китая: история, культура, современное общество», номер госрегистрации № AAAA-A17-117021310269-9). 


\title{
Список литературы
}

Бадараев Д.Д. 2014. Современные «ниндзя»: масштабы и последствия для Монголии. - Власть. № 4. С. 130-134.

Бадараев Д.Д., Бреславский А.С., Гомбожапов А.Д., Жамбалова С.Г., Цыбенов Б.Д. 2017. Кочевничество и миграции в современной Монголии: монография. Улан-Удэ: Изд-во БНЦ СО РАН. 168 с.

Грайворонский В.В. 2017. Монголия в начале ХХІ в. (политика, экономика, общество). М.: Изд-во ИВ РАН. 352 с.

BADARAEV Damdin Dorzhievich, Cand.Sci. (Soc.), Associate Professor; Senior Research Associate of the Institute for Mongolian, Buddhist and Tibetan Studies, Siberian Branch of Russian Academy of Sciences (6 Sakhyanovoj St, UlanUde, Republic of Buryatia, Russia, 670047; damdin80@mail.ru)

BADONOV Alexei Malanovich, Cand.Sci. (Soc.), Associate Professor of the Chair of Social Work Theory, Buryat State University(24a Smolina St, Ulan-Ude, Republic of Buryatia, Russia,670000; badonov@mail.ru)

\section{THE IMPACT OF GLOBALIZATION ON THE LIFE SUPPORT SYSTEM OF MONGOLIAN SOCIETY}

\begin{abstract}
The article is devoted to the consideration of features of the life support system of Mongolian society, changing under the influence of globalization processes in various spheres of Mongolia's life. Based on the statistical data and indicators of the human development index of society, the authors determine and analyze the main trends in the society changes, such as strengthening the centripetal processes in the country, which leads to the importance of cities in the life of the Ulaanbaatar population. However, it leads to a numerous problems related to ensuring the normal functioning of the life support system of Mongolian society.
\end{abstract}

Keywords: globalization, life support system, Mongolia, human development index, traditional culture 